\title{
Role models, mentoring and university applications - evidence from a crossover randomised controlled trial in the United Kingdom ${ }^{\mathrm{i}}$
}

Simon Burgess, University of Bristol

Raj Chande, Behavioural Insights Team

Catherine Dilnot, Oxford Brookes University

Eliza Kozman, Behavioural Insights Team

Lindsey Macmillan, UCL Institute of Education

Michael Sanders, Behavioural Insights Team and KCL

Contact author: michael.sanders@bi.team; +44 7557143574;

Behavioural Insights Team, 2nd Floor, 4 Matthew Parker Street, London, SW1H 9NP. UK

\begin{abstract}
We conduct a randomised controlled trial in the South West of England to evaluate a policy to encourage students from poorer backgrounds to apply to selective universities. Current university students visited local schools and colleges, providing accurate information on the costs and benefits of university, and giving inspirational talks about making that decision. We find that there is a significant effect on the likelihood of students successfully applying to a selective university, but weaker effects on other outcomes. We find that effects are largest for students attending further education colleges, which typically cater for more disadvantaged students (in our sample, $6.2 \%$ of students in schools are eligible for free school meals compared to $7.4 \%$ in colleges) and offer a wider range of vocational courses. We suggest avenues for future research in this area.
\end{abstract}

Key words widening participation; university; social mobility; RCT

\section{Introduction}

Education is central to an individual's chances of high earnings, a satisfying job, good health and a long life (Burgess, 2016). However, access to education in England is uneven, with young people's socio-economic status (or rather, that of their parents), strongly predicting their educational attainment and highest qualifications. 
This situation has led to a growing focus on 'widening participation' (WP) improving access to higher education (HE) for young people from low-income families. As the majority of UK universities receive public funding, a range of policy levers have been used to drive this agenda, and English universities and those wishing to charge the highest permitted rate of tuition fees are now required to develop programmes of activity in pursuit of WP targets (Harrison \& Waller, 2017). As a result, in 2017-18 English higher education providers will collectively invest $£ 833.5$ million into such activities (OFFA, 2016).

Despite many years of WP policy, participation in UK HE is still heavily patterned by socioeconomic status, particularly at highly selective universities (Chowdry et al., 2013). Previous research suggests that students from the top socioeconomic quintile are approximately three times more likely to go to university, and seven times more likely to go to a highly selective university, than those in the lowest quintile (Anders, 2012; Crawford \& Greaves, 2015). A number of studies have found that these disparities are almost, or entirely eliminated, once prior attainment is taken into consideration, suggesting that main cause of inequality in university participation is the impact of socioeconomic status on achievement at school (Anders, 2012; Chowdry et al., 2013; Crawford, \& Greaves, 2015; MarcenaroGutierrez, Galindo-Rueda \& Vignoles, 2007). However, even after attainment is taken into account, there are unexplained gaps in participation (Anders, 2012; Crawford \& Greaves, 2015). There is evidence to suggest that differential application behaviour may play a part in creating these gaps - in both the UK and US it seems that students from lower socioeconomic groups are less likely to apply to the most selective universities, even when they have the right grades (Anders, 2012; Hoxby \& Avery 2012).

On this basis, there is a case to develop interventions designed to encourage low socioeconomic status students to make more ambitious university choices. However, this idea is predicated on the assumption that these students have the same chance of a successful application as wealthier students, conditional on attainment. There are a number of studies which challenge this assumption and 
suggest that poorer students (and those from certain minority ethnic groups) are less likely to be made an offer than similarly qualified peers; therefore, to establish the validity of encouraging applications to selective universities, it is also important to consider whether these applications are successful (Boliver, 2013; Boliver, 2016; Shiner \& Modood, 2002; Zimdars, Sullivan \& Heath, 2009). To this end, our study sought to test whether a talk from an inspirational role model could boost applications to selective universities, but also examined whether these applicants were offered and accepted a place.

We ran a randomised controlled trial over three years using existing university undergraduates to go into local schools and colleges to deliver inspirational talks, provide a clear guide to the true costs and benefits of going to university, and to undertake additional small-scale tutoring. ${ }^{\text {ii }}$ We recruited students from the University of Bristol, mostly first years, to act as volunteer mentors, and we recruited local schools and colleges, typically from the more disadvantaged areas in and around Bristol that send comparatively few of their students on to University of Bristol or similarly selective universities. Further details on the operation of the intervention are provided later in this paper.

The results suggest that the intervention was effective at increasing applications to selective universities. Moreover, the same pattern was observed with respect to acceptances - our best proxy for whether a student takes up an offer. The point estimates are all positive and while statistical power is low, the estimates reach standard levels of significance in a number of cases. Quantitative significance is also important and the point estimates indicate effects that are economically meaningful, particularly for a very low-cost intervention. It is interesting that the effects are stronger in further education colleges, typically catering for more disadvantaged students. Recent evidence from a study using linked administrative data suggests students entering university with A-levels from FE college are the least privileged institution type group to enter university. Their average socioeconomic status quintile, based on the whole age 16 cohort, including those not continuing in education or taking other qualifications, was 3.3 compared with 3.8 for non-selective school students (Dilnot, 2018). 
The implications of the trial are twofold. First, the trial builds on an emerging body of research which demonstrates how role models can be an effective mechanism for influencing student outcomes (Nguyen, 2008; Riley, 2017; Silva, Sanders \& Ni Chonaire, 2016). Second, the findings suggest there is some degree of mismatch between student ability and aspirations and supports the use of other interventions which seek to encourage able students from low-income backgrounds to apply to more selective universities (Anders, 2012; Hoxby \& Avery, 2012).

The remainder of this paper is organised as follows: in the next section we review evidence which supports our intervention design. Following that, we set out our experiment design, followed by data description and analysis. Finally, we provide a discussion of our results and conclusions.

\section{Evidence Review}

The process by which students decide where to go to university is complex and is influenced by a range of cultural, economic and personal factors. (Bowes et al., 2015; Callender \& Jackson, 2008; Connor et al., 1999; Gibbons \& Vignoles, 2012; Moogan \& Baron, 2003). One clear finding from the literature is that students from lower socioeconomic groups are more likely to rely on 'hot information' from their social networks and consequently lack the timely, unbiased information they need to optimise their university choices (Archer, Hollingworth. \& Halsall, 2007; Ball \& Vincent, 1998). Moreover, issues around identity can play an important role in shaping decisions about where to go to university - for example, students from lower socioeconomic groups may perceive the most selective universities as innately 'middle-class' environments where they will not 'fit in' (Archer \& Hutchings, 2000; Ball et al., 2002; Reay et al., 2001). These findings suggest that, to encourage students from lower socioeconomic groups to apply to selective universities, as a minimum it is necessary to tackle both issues: the informational and identity-based barriers to applying. The use of undergraduate students in WP activities is one such strategy. 
Among the early users of so called 'student-ambassadors' - now a mainstay of intuitional activity - was the government-funded 'Aimhigher Associates' scheme (Sanders \& Higham, 2012). Between 2009 and 2010, one in every 150 students in Years 9-13 (ages 13-17) engaged with HE students who were hired to deliver aspiration and attainment-raising activities in schools (Higher Education Funding Council for England, 2011). It is important to note that in our study we focus on student ambassadors as the agents of relatively light-touch engagement (e.g. as part of campus visits or summer schools) as opposed to more intensive interventions such as sustained tutoring or mentoring. The Associates scheme generated a sizable body of 'grey' evaluative evidence which supports the use of student ambassadors in both capacities, but academic research on the latter is relatively limited (Rodger \& Burgess, 2010; Sanders \& Higham, 2012).

The most relevant literature qualitative in nature and focuses on how the use of student ambassador schemes impact not only on school students but the ambassadors themselves (Sanders \& Higham, 2012). A number of qualitative studies characterise student ambassadors 'role models' - a source of inspiration for students to look up to who can expand pupils' horizons about what is possible (Austin \& Hatt, 2005; Gartland, 2015; Ylonen, 2010). For example, one predominantly ethnographic study of outreach at two London universities, highlighted how informal interactions allowed students to develop shared 'learner identities' with student ambassadors and, in doing so, helped them understand the reality of a university education and how they themselves could belong in this setting (Gartland, 2015).

Crucially, beyond acting as role models, student ambassadors appear to 'bridge the gap' between universities and students in terms of information provision. As discussed previously, students from lower socioeconomic groups are observed to rely more heavily on 'hot' information from people in their networks (Ball \& Vincent, 1998). In one study which employed focus groups and questionnaires to explore attitudes to information provision among new undergraduates, student ambassadors were highlighted as an important source of information for prospective applicants (Slack et al., 2014). Student ambassadors are generally 
regarded as a credible source of information as opposed to 'cold' data provided by institutions (Hatt, Baxter \& Tate, 2009; Slack et al., 2014).

While these studies suggest that exposure to student ambassadors is likely to be beneficial for students, there is a lack of associated quantitative research. However, an emerging body of experimental research, rooted in behavioural science, is starting to test the efficacy of discrete interventions to promote positive education outcomes (French \& Oreopoulos, 2017; Lavecchia, Liu, \& Oreopoulos, 2014).

Some of this experimental work focuses on role models and provides new experimental evidence to complement the studies discussed above. For example, a recent randomised controlled trial in British secondary schools found that students who were exposed to a talk from an inspirational role model discussing the benefits of a university education were approximately eight percentage points more likely to express an interest in attending university compared to those in the control group (55.8\% compared to 48.0\%) (Silva, Sanders, \& Ni Chonaire, 2016). Similar interventions have also been shown to improve academic performance: exposure to a role model from a low-income background has been shown to increase test scores by 0.27 standard deviations for poor Madagascan students (Nguyen, 2008). In another study, Ugandan students who watched a film about an aspirational female role model were 11 percentage points less likely to fail an end-of-school maths exam (Riley, 2017).

In addition to raising aspirations and attainment, there is also evidence that role models may indeed influence university application behaviour, even via indirect contact. A recent UK study found that an inspirational letter from a university student from a low-income background sent to 16 to 17 year olds with good grades in schools (where they were likely to reject university or go to the most local institution) increased the proportion of young people accepting an offer from a selective university by $30 \%$ (Sanders, Chande \& Selley, 2017). Our study seeks to build on this evidence that a light-touch role model intervention can have a disproportionately big effect on university application behaviour. 


\section{Experiment Design}

\section{Interventions}

Participants in our trial could receive one of two treatments: either they were in the control group, in which case they received no additional support encouraging them to attend university compared to their school's business as usual, or they were assigned to the 'talk' condition. The control condition is better described as 'business as usual': it does not mean that schools had to stop any related activity; it simply means that they get no extra help from the intervention.

The intervention was delivered by student mentors recruited from the University of Bristol. Recruitment was conducted at the Freshers' and Volunteers' Fairs iii, and sent via email through course mailings. No specific attempt was made to recruit mentors from any particular background. Informal conversations at training days revealed that many mentors were from widening participation backgrounds as the project was of particular interest to them, but no formal record of their background was made. Mentors received training from Teach First (a social enterprise with a mission to improve education for young people from poorer backgrounds) in the first year, and in subsequent years were trained by a combination of Teach First and returning mentors from the previous year. All students were subject to Disclosure and Barring Service checks, which are the standard checks in the UK to ensure that mentors do not have a criminal record that would preclude them from working with young people. Participants' travel to schools was paid for, but otherwise their involvement was voluntary and unpaid.

Student mentors visited the schools and delivered 'Inspire Talks' to full year groups of students. These talks were intended to be both informational and inspirational and focused on how the mentor had progressed to university and what it was like to attend. Schools were asked for convenient times and dates for the visits and mentors were allocated to schools according to their availability. Mentors devised their presentations individually to reflect their own experience of life as University of Bristol students. An example of a successful presentation was provided via a mentors' Facebook group. Mentors were asked to cover the 
stimulating academic environment, the opportunities to get involved in sports and societies, the vibrant social life and what they wished they had known about university when they were at school. The example presentation included mentions of societies at other selective universities, a timetable of a typical week and photographs of social events.

We also designed and set up an online tool to help explain the financial benefits and costs from attending a university like the University of Bristol. This was presented by the mentors, although in the final year they switched to conveying the main points on slides. The main messages conveyed were that graduates earn more than nongraduates, that anyone can afford to go to university and that you only pay back what you can afford.

The combined experience of university presentation, finance presentation and question-and-answer sessions were planned to take 50 minutes. At the end of each year, schools and mentors were asked to provide feedback on the sessions, which was not collected systematically enough to allow for analysis, but was generally positive.

\section{Experiment Design}

The experiment ran from the 2013/14 to the 2015/16 academic year. It was conducted as a cluster randomised, cross-over design randomised controlled trial. A stylised graphical representation of this design can be seen below. In a crossover trial, school/year pairs (for example, the cohort of School X that will graduate in year $\mathrm{Y}$ ), are randomised to one of the three conditions, where stratification occurs at the level of the school - as such, each school contains at least one year group that receives each of our treatment conditions. This design was selected in order to maximise schools' adherence with the trial (as all schools in the trial receive at least one intervention, they all have some incentive to continue), and to maximise statistical power.

\section{FIGURE 1 HERE}




\section{Sample}

Schools were recruited for the trial through direct mail contacts. Schools were chosen close to the University of Bristol, due to the practicality of implementation, and because the aim was explicitly to 'widen participation' from local schools. The region covered by our trial, and the schools included, can be seen in Figure 2 below. Although the majority of schools in our sample are secondary schools, there are a few relatively larger further education colleges in the trial. In total 36 schools and colleges were recruited and took part in the study.

FIGURE 2 HERE

\section{Analysis and Data Description}

\section{Data Description}

We have three main sources of data: our own assignment data, data from the Universities and Colleges Admission Service (UCAS), and data provided by the University of Bristol. These data cover all applications to university from our trial schools and colleges for academic years ranging from 2001 to 2016 (the latest year for which data are available). These data are merged together by schools and colleges on their unique reference number (URN) and the application cycle year of each cohort.

UCAS data contains four of our five outcome measures - the number of applications from a school to any university, the number of applications from a school to any Russell Group University ${ }^{\mathrm{iv}}$, and how many of these applications result in acceptances - that is, cases where an application to a university attracts an offer which subsequently is accepted by the student. This is the best proxy we have for whether a student attends that university. Each student can make up to five applications, unless they are applying to study medicine, in which case they can apply to four. Because almost all students will apply for either 0 or 5 universities 
(there is no marginal cost to each application, either financial or effort), we interpret an increase in the number of applications by 5 as an increase in the number of students applying to university by 1 . For Russell Group applications this is less clear-cut, as applications to Russell Group universities can take up to any number of the students' five applications, or none, and so an increase in Russell Group applications by 5 might be interpreted in a number of ways: either one student applying to five Russell Group universities, 5 students applying to one each, and so on. As each student will typically only accept one offer, it is more straightforward to interpret this variable. Data from the University of Bristol contains data on all applications to the University of Bristol for our trial schools.

In total our data contain 36 institutions, of which seven are colleges and 24 are schools with sixth forms, and five are 11-16 schools, observed from the 2002 to the 2017 application cycle. The majority of schools appear in our data 14 times, with some schools observed on fewer occasions either due to the schools' being established during the period covered by our data or changing their name or status (and hence their URN) and their prior details not being known.

\section{Censoring}

All of our data are provided at the school/year level, and data provided by UCAS are subject to censoring rules to protect the anonymity of university applicants. These censoring rules mean that where fewer than 2 applicants are listed in a category, this is reported as 0 . Similarly, any number between 2 and 5 is rounded to a 5. Therefore, we cannot be sure whether $0 \mathrm{~s}$ or $5 \mathrm{~s}$ represent real data or are an artefact of censoring; this introduces a risk of bias into our analysis. Randomisation should control for this issue, but it is necessary to be cautious in the interpretation of our point estimates.

\section{Time Period}

Data from our trial period are combined with historical data in order to maximise statistical power, and to minimise the risk of bias due to the relatively small number of clusters to be randomised, by allowing us to control more fully for 
school-specific fixed effects and for the time trend of applications school by school.

\section{Analytical Strategy and Results}

Using this data, we create a panel of schools/colleges: the school (subscript $s$ below) is the cross-sectional unit, and application cycle (cohort) is the time variable (subscript $t$ below). For each of our five outcome measures (applications and acceptances to any/Russell Group universities, applications to Bristol) we regress the outcome on the treatment variable, a time trend, and a vector of school fixed effects. Because our unit of observation and our unit of randomisation are the same, we do not cluster our standard errors. The results of our analysis are in Table 1.

\section{TABLE 1 HERE}

Our findings are positive but not conclusive. For all of our variables of interest we see a positive relationship between treatment and the outcome measure. However, these are not generally statistically significant due to a combination of factors: principally small effect sizes associated with our intervention; a relatively small sample; the lack of availability of individual data; and the greater than anticipated level of variability in the outcome measures.

We find a substantial increase in the number of applications to Russell Group universities as a result of treatment, of 80 applications per school/college ${ }^{\mathrm{v}}$, which is statistically significant at the $10 \%$ level. Given a control group mean of 124 , this is a very sizeable quantitative effect, which we investigate further in the secondary analysis.

We find a positive and significant increase in the number of people accepting offers from Russell Group universities (see Figure 3, below), which is our most reliable proxy for attending that sort of institution - and this is statistically significant at the $1 \%$ level. These findings are robust to alternative specifications (including the inclusion of time fixed effects rather than a time trend) in the direction and size of the point estimate, but not in terms of statistical significance ${ }^{\mathrm{vi}}$. Taken together, the relatively larger impact on the University of Bristol role 
models on Russell Group applications than applications for all universities suggest that the intervention worked at least in part to boost the aspirations of those students already most likely to attend university.

\section{FIGURE 3 HERE}

The point estimates suggest a 5\% increase in applications to the University of Bristol itself, though this is also not statistically significant. Although speculative, this relatively smaller effect, compared to the effect on Russell Group applications (of which Bristol is a subset), suggests that higher-aspiration students (those that apply to Russell Group universities) are also more likely to move further away from home.

Our point estimates of the treatment effect across our outcome measures excluding the University of Bristol applications is large in relative terms. One explanation for this is that a modest treatment effect in small schools is being exaggerated by the censoring rules described above, while another is that our treatment effect is biggest in larger institutions. Although the number of students enrolled is not known, we do know that colleges are typically larger institutions, drawing their cohorts from many schools.

To investigate further, we therefore conduct analysis by splitting the sample between further education colleges and schools, shown in Tables 2 and 3 .

\section{TABLE 2 HERE}

\section{TABLE 3 HERE}

In these tables we see additional evidence that our treatment is stronger for students in further education colleges. As well as having significantly more students, leading to significantly more applications overall, the treatment effect is statistically significant and positive for both applications and acceptances to Russell Group universities (Figure 4). The effect remains positive but statistically insignificant for students in schools (Figure 5). There are no significant results for applications to the University of Bristol.

\section{FIGURE 4 HERE}


FIGURE 5 HERE

\section{Discussion}

We have conducted a randomised controlled trial testing the impact of talks from current students at the University of Bristol on applications to universities by students from local schools and colleges. Although our findings are limited by data availability and the scale of the trial, we have found indicative evidence supporting the hypothesis that an inspirational talk from a current student encourages students to apply to more universities. We observe in our data that this is particularly concentrated on applications for more selective Russell Group universities than on universities overall. This is likely to be because the inspirational students were themselves attending a Russell Group university and the exemplar talk provided for them to adapt into their own presentation included examples of societies at other selective universities.

This study complements a body of qualitative evidence that student ambassadors can be an effective component of WP activities (Gartland, 2015; Sanders \& Higham, 2012; Slack et al., 2014). It also builds on an emerging body of experimental research that a brief exposure to an inspirational role model can influence student outcomes and applications to selective universities in particular (Nguyen, 2008; Riley, 2017; Sanders, Chande \& Selley, 2017; Silva, Sanders \& Ni Chonaire, 2016). Moreover, because the intervention led to successful applications (as far as we are able to discern), our findings also support recent analysis which suggests students from lower socioeconomic groups are less likely to apply to the most selective universities, even when they have the right grades (Anders, 2012; Hoxby \& Avery, 2012). Clearly further research is needed to confirm (or not) these suggestive findings. But if the sizeable point effects we have shown here are confirmed, then this intervention merits inclusion in the WP policy portfolios of universities.

We find a differential impact of our treatment for colleges compared to schools; all point estimates are positive but much larger in colleges and more precisely 
determined. Only some of the effects are statistically significant, but all are suggestive of a positive effect. Speculating as to the mechanism underlying this finding, it is possible that college environments, which typically contain more students, are less conducive to personal support for application to university and selective university in particular, and so there may be less time spent, per student, in encouraging them to apply and in overcoming social or economic barriers.

Alternatively, it could be that the selection of students into these further education colleges is a relevant factor. Because colleges offer a wider variety of courses, it could be that students who select into these institutions are interested in pursuing career less well catered by the curriculum of the school they have left (such as fashion or art history or in some cases, economics) and may not be aware of the benefit or options of university in the absence of our intervention. Future qualitative and quantitative research could investigate this more fully.

Another avenue for future research is the role of characteristics. A number of studies suggest similarity can be an important factor in the efficacy of student ambassadors and role models more generally (Dasgupta, 2011; Gartland, 2015; Ray, 2006). However, there is a lack of evidence to support this claim - therefore, future studies will examine the importance of perceived and actual similarity as a mediator of role-model efficacy.

We would argue that our intervention offers positive outcomes for all participants. The students will almost surely be better off, being accepted at selective universities where they would not otherwise have applied to. Student ambassadors themselves have been shown to gain in a number of ways: the addition to their CVs, training and experience, improved 'soft skills', plus the 'warm glow' from volunteering in their adopted city (Sanders \& Higham, 2012). Finally, universities gain from an increased capability to attract talent from a broader and more diverse pool, an enhanced student experience with more local volunteering opportunities, and local reputational gain. 


\begin{abstract}
${ }^{i}$ We are very grateful to Julia Carey, Project Manager; Abbi Stoneman, Christine Spencer and Maggi Walton, Project administrators; Amy Butterworth, Deputy Head of Admissions at UoB helped with understanding data and provided admissions data; Kate Guest from Teach First ran the mentor training; and all the student mentors; and Louise Jones for research assistance We are also very grateful to the University of Bristol for co-funding this project.
\end{abstract}

ii The inspirational talks and information provision were delivered at school level and are evaluated in this paper. The tutoring was at student level and we are evaluating that in a separate paper.

iii These events take place early in the school year and are organised by the university's students' union.

iv The Russell Group is a membership body of good British universities, which includes the University of Bristol. As it is a membership body, institutions can join it, and pay fees to be members. As such, it is not a perfect predictor of being a 'selective' university, although it typically represents most of the best universities in the UK.

${ }^{v}$ As most students can make a maximum of five applications, and rarely make fewer than this, an increase of 80 applications can be thought of as an increase of 16 students making applications.

${ }^{\text {vi }}$ We have selected our empirical strategy based on maximising power in the limited dataset that we have, and therefore have selected the model with the highest adjusted $\mathrm{R}$ squared as our primary analysis. 


\section{References}

Anders, J. (2012) 'The link between household income, university applications and university attendance', Fiscal Studies, 33, 2: 185-210.

Archer, L., Hollingworth, S. and Halsall, A. (2007) 'University's not for me - I'm a Nike person: urban, working-class young people's negotiations of "style", identity and educational engagement.' Sociology, 41, 2: 219-237.

Archer, L. and Hutchings, M. (2000) 'Bettering yourself'? Discourses of risk, cost and benefit in ethnically diverse, young working-class non-participants' constructions of higher education', British Journal of Sociology of Education, 21, 4, 555-574.

Austin, M. and Hatt, S. (2005) 'The messengers are the message: a study of the effects of employing higher education student ambassadors to work with school students', Widening Participation and Lifelong Learning, 7, 1: 1-8.

Ball, S.J. and Vincent, C. (1998) 'I Heard it on the grapevine: "hot" knowledge and school choice', British Journal of Sociology of Education, 19, 3: 377-400.

Ball, S.J., Davies, J., David, M. and Reay, D. (2002) 'Classification and judgement: social class and the cognitive structures of choice of higher education', British Journal of Sociology of Education, 23, 1: 51-72.

Boliver, V. (2013) 'How fair is access to more prestigious UK universities?', The British Journal of Sociology, 64, 2: 344-364.

Boliver, V. (2016) 'Exploring ethnic inequalities in admission to Russell Group universities', Sociology, 50, 2: 247-266.

Bowes L, Evans J, Nathwani T, Birkin G, Boyd A, Holmes C, Thomas L and Jones S. (2015) Understanding progression into higher education for disadvantaged and under-represented groups. London: A report for the Department for Business, Innovation and Skills.

Burgess, S. (2016) 'Human Capital and Education: the State of the Art in the Economics of Education [Online]. Available at http://ftp.iza.org/dp9885.pdf (accessed: 26 October 2018).

Callender, C. and Jackson, J. (2008) Does the fear of debt constrain choice of university and subject of study? Studies in Higher Education, 33, 4: 405429.

Chowdry, H., Crawford C., Deardon, L., Goodman, A. and Vignoles, A. (2013) 'Widening participation in higher education: analysis using linked administrative data', Journal of the Royal Statistical Society: Series A (Statistics in Society), 176, 2: 431-457. 
Connor, H., Burton, R., Pearson, R., Pollard, E. and Regan, J. (1999) Making the Right Choice: How Students Choose Universities and Colleges. London: CVCP.

Crawford, C., and Greaves, E. (2015) Socio-economic, Ethnic and Gender Differences in HE Participation. BIS Research Paper no.186. Department for Business, Innovation and Skills.

Dasgupta, N. (2011) 'Ingroup experts and peers as social vaccines who inoculate the self-concept: the stereotype inoculation model', Psychological Inquiry, 22, 4: 231-246.

Dilnot, C. (2018) 'The relationship between A-level subject choice and league table score of university attended: the "facilitating", the "less suitable", and the counter-intuitive', Oxford Review of Education, 44, 1: 118-137.

French, R. and Oreopoulos, P. (2017) 'Behavioral barriers transitioning to college', Labour Economics, 47, 48-63.

Gartland, C. (2015) Student ambassadors: "Role-models", learning practices and identities', British Journal of Sociology of Education, 36, 8: 1192-1211.

Gibbons, S., and Vignoles, A. (2012) 'Geography, choice and participation in higher education in England', Regional Science and Urban Economics, 42, 1-2: 98-113.

Harrison, N., and Waller, R. (2017) 'Success and impact in widening participation policy: what works and how do we know?', Higher Education Policy, 30, 2: $141-160$.

Hatt, S., Baxter, A. and Tate, J. (2009) “'It was definitely a turning point!” A review of Aimhigher summer schools in the south west of England', Journal of Further and Higher Education, 33, 4, 333-346.

Higher Education Funding Council for England (2011) Aimhigher Associates scheme, Patterns of participation during the first year.

Hoxby, C.M. and Avery, C. (2012) The Missing 'One-offs': The Hidden Supply of High-Achieving, Low Income Students (No. w18586). National Bureau of Economic Research.

Lavecchia, A.M., Liu, H. and Oreopoulos, P. (2014) Behavioral Economics of Education: Progress and Possibilities (No. w20609). National Bureau of Economic Research.

Marcenaro-Gutierrez, O., Galindo-Rueda, F. and Vignoles, A. (2007) 'Who actually goes to university?', Empirical Economics, 32, 2-3: 333-357. 
Moogan, Y.J. and Baron, S. (2003) 'An analysis of student characteristics within the student decision making process', Journal of Further and Higher Education, 27, 3: 271-287.

Nguyen, T. (2008) 'Information, role models and perceived returns to education: Experimental evidence from Madagascar’, Unpublished manuscript, 6.

OFFA (2016) 2017-18 access agreements: institutional expenditure and fee levels.

Ray, D. (2006) 'Aspirations, poverty, and economic change', Understanding Poverty, 409421.

Reay, D., Davies, J., David, M. and Ball, S. J. (2001) 'Choices of degree or degrees of choice? Class, "race" and the higher education choice process', Sociology, 35, 4: 855-874.

Riley, E. (2017) Increasing students' aspirations: the impact of Queen of Katwe on students' educational attainment', in CSAE Working Paper WPS/2017-13.

Rodger, J. and Burgess, M. (2010) 'Qualitative evaluation of the Aimhigher Associates programme: pathfinder', Report to HEFCE by York Consulting.

Sanders, J. and Higham, L. (2012) 'The role of higher education students in widening access, retention and success', A Literature Synthesis of the Widening Access, Student Retention and Success National Programmes Archive.

Sanders, M., Chande, R. and Selley, E. (2017) Encouraging People into University, United Kingdom: Department of Education.

Shiner, M. and Modood, T. (2002) 'Help or hindrance? Higher education and the route to ethnic equality', British Journal of Sociology of Education, 23, 2: 209-232.

Silva, A., Sanders, M. and Ni Chonaire, A.N. (2016) Does the Heart Rule the Head? Economic and Emotional Incentives for University Attendance, London: Behavioural Insights Team.

Slack, K., Mangan, J., Hughes, A. and Davies, P. (2014) “"Hot”, “cold” and "warm" information and higher education decision-making', British Journal of Sociology of Education, 35, 2: 204-223.

UCAS (2017) End of Cycle Report, 2017.

Ylonen, A. (2010) 'The role of student ambassadors in higher education: an uneasy association between autonomy and accountability', Journal of Further and Higher Education, 34, 1: 97-104. 
Zimdars, A., Sullivan, A. and Heath, A. (2009) 'Elite higher education admissions in the arts and sciences: Is cultural capital the key?' Sociology, 43, 4: 648666. 
Figure 1: Stylised graph denoting school/cohort pairs randomised to treatment (dark grey) or control (white)

School Cohorts
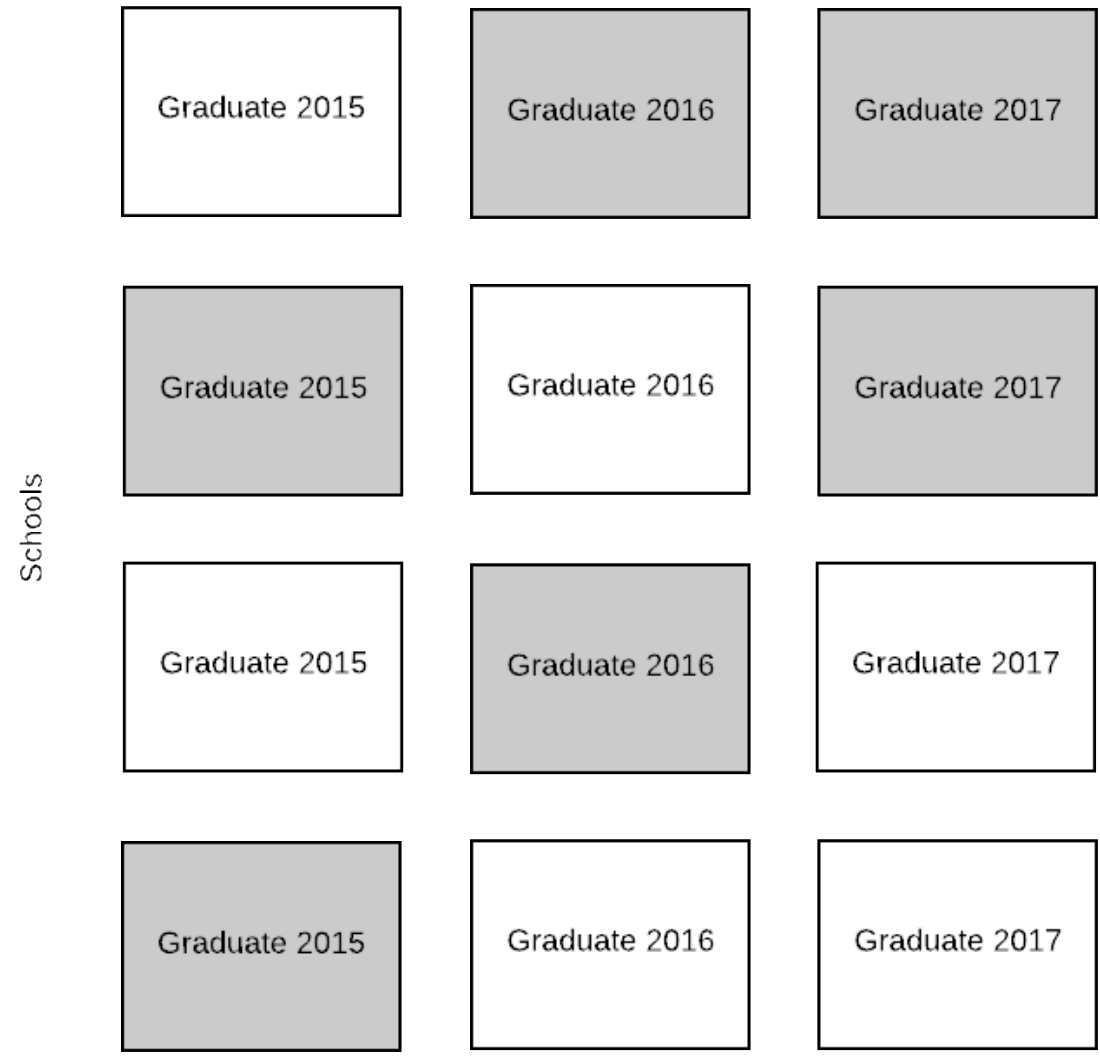
Table 1: Results of primary analysis (School/College Fixed Effects)

\begin{tabular}{|c|c|c|c|c|c|}
\hline & (1) & $(2)$ & (3) & (4) & (5) \\
\hline & $\begin{array}{l}\text { Total } \\
\text { Applications }\end{array}$ & $\begin{array}{l}\text { Total RG } \\
\text { Applications }\end{array}$ & $\begin{array}{l}\text { Bristol } \\
\text { Applications }\end{array}$ & $\begin{array}{l}\text { Total } \\
\text { Acceptances }\end{array}$ & $\begin{array}{l}\text { Total RG } \\
\text { acceptances }\end{array}$ \\
\hline \multirow[t]{2}{*}{ Treatment } & 151.309 & $80.127+$ & 0.882 & 26.415 & $27.314^{* *}$ \\
\hline & (279.468) & $(47.942)$ & (7.405) & (53.375) & $(10.070)$ \\
\hline \multirow[t]{2}{*}{ Constant } & $-2.49 e+04+$ & -2773.230 & 20.764 & $-6786.789 *$ & $-2334.378 * * *$ \\
\hline & $(16343.140)$ & $(2803.625)$ & (567.358) & (3121.355) & $(588.872)$ \\
\hline $\begin{array}{l}\text { Time } \\
\text { Trend }\end{array}$ & Yes & Yes & Yes & Yes & Yes \\
\hline $\begin{array}{l}\text { Cluster } \\
\text { Fixed } \\
\text { effects }\end{array}$ & Yes & Yes & Yes & Yes & Yes \\
\hline $\begin{array}{l}\text { Trial } \\
\text { Period } \\
\text { Control } \\
\text { Group } \\
\text { Mean }\end{array}$ & 691 & 124 & 17 & 130 & 29 \\
\hline $\mathrm{N}$ & 445 & 445 & 457 & 445 & 445 \\
\hline
\end{tabular}

Robust Standard Errors in Parentheses

$+\mathrm{p}<0.1, * \mathrm{p}<0.05, * * \mathrm{p}<0.01, * * * \mathrm{p}<0.001$ 
Table 2: Results of secondary analysis, evaluating treatment effect on colleges (College fixed effects)

\begin{tabular}{|c|c|c|c|c|c|}
\hline & (1) & (2) & (3) & (4) & (5) \\
\hline & $\begin{array}{l}\text { Total } \\
\text { Applications }\end{array}$ & $\begin{array}{l}\text { Total RG } \\
\text { Applications }\end{array}$ & $\begin{array}{l}\text { Bristol } \\
\text { Applications }\end{array}$ & $\begin{array}{l}\text { Total } \\
\text { Acceptances }\end{array}$ & $\begin{array}{l}\text { Total RG } \\
\text { acceptances }\end{array}$ \\
\hline \multirow[t]{2}{*}{ Treatment } & 453.415 & $243.710 *$ & -2.889 & 69.103 & $81.849 * *$ \\
\hline & $(663.311)$ & (115.154) & $(20.431)$ & (131.464) & $(25.781)$ \\
\hline \multirow[t]{2}{*}{ Constant } & $-4.03 e+04$ & -1283.427 & 558.590 & $-1.29 \mathrm{e}+04+$ & $-3367.286^{*}$ \\
\hline & $(42379.763)$ & (7357.346) & (1736.666) & (8399.387) & $(1647.209)$ \\
\hline $\begin{array}{l}\text { Time } \\
\text { Trend }\end{array}$ & Yes & Yes & Yes & Yes & Yes \\
\hline $\begin{array}{l}\text { Cluster } \\
\text { Fixed } \\
\text { Effects }\end{array}$ & Yes & Yes & Yes & Yes & Yes \\
\hline $\begin{array}{l}\text { Control } \\
\text { Group } \\
\text { Trial } \\
\text { Period } \\
\text { Mean }\end{array}$ & 1617 & 234 & 48 & 315 & 54 \\
\hline $\mathrm{N}$ & 101 & 101 & 103 & 101 & 101 \\
\hline
\end{tabular}

Robust Standard Errors in Parentheses

$+\mathrm{p}<0.1,{ }^{*} \mathrm{p}<0.05, * * \mathrm{p}<0.01,{ }^{* * *} \mathrm{p}<0.001$ 
Table 3: Results of secondary analysis, evaluating treatment effects on schools (School fixed effects)

\begin{tabular}{|c|c|c|c|c|c|}
\hline & (1) & (2) & (3) & (4) & (5) \\
\hline & $\begin{array}{l}\text { Total } \\
\text { Applications }\end{array}$ & $\begin{array}{l}\text { Total RG } \\
\text { Applications }\end{array}$ & $\begin{array}{l}\text { Bristol } \\
\text { Applications }\end{array}$ & $\begin{array}{l}\text { Total } \\
\text { Acceptances }\end{array}$ & $\begin{array}{l}\text { Total RG } \\
\text { acceptances }\end{array}$ \\
\hline \multirow[t]{2}{*}{ Treatment } & 13.091 & 24.343 & -1.108 & 4.100 & 9.075 \\
\hline & (121.139) & (38.382) & (2.307) & $(20.501)$ & (7.203) \\
\hline \multirow[t]{2}{*}{ Constant } & -6643.842 & -1101.701 & -99.629 & $-2390.100 *$ & $-1144.580 * *$ \\
\hline & $(6313.782)$ & $(2000.444)$ & $(170.465)$ & (1068.509) & $(375.430)$ \\
\hline $\begin{array}{l}\text { Time } \\
\text { Trend }\end{array}$ & Yes & Yes & Yes & Yes & Yes \\
\hline $\begin{array}{l}\text { Cluster } \\
\text { Fixed } \\
\text { Effects }\end{array}$ & Yes & Yes & Yes & Yes & Yes \\
\hline $\begin{array}{l}\text { Control } \\
\text { Group } \\
\text { Trial } \\
\text { Period } \\
\text { Mean }\end{array}$ & 362 & 86 & 20 & 64 & 20 \\
\hline $\mathrm{N}$ & 338 & 338 & 354 & 338 & 338 \\
\hline
\end{tabular}

Robust Standard Errors in Parentheses

$+\mathrm{p}<0.1,{ }^{*} \mathrm{p}<0.05, * * \mathrm{p}<0.01,{ }^{* * *} \mathrm{p}<0.001$ 
Figure 2: School Locations

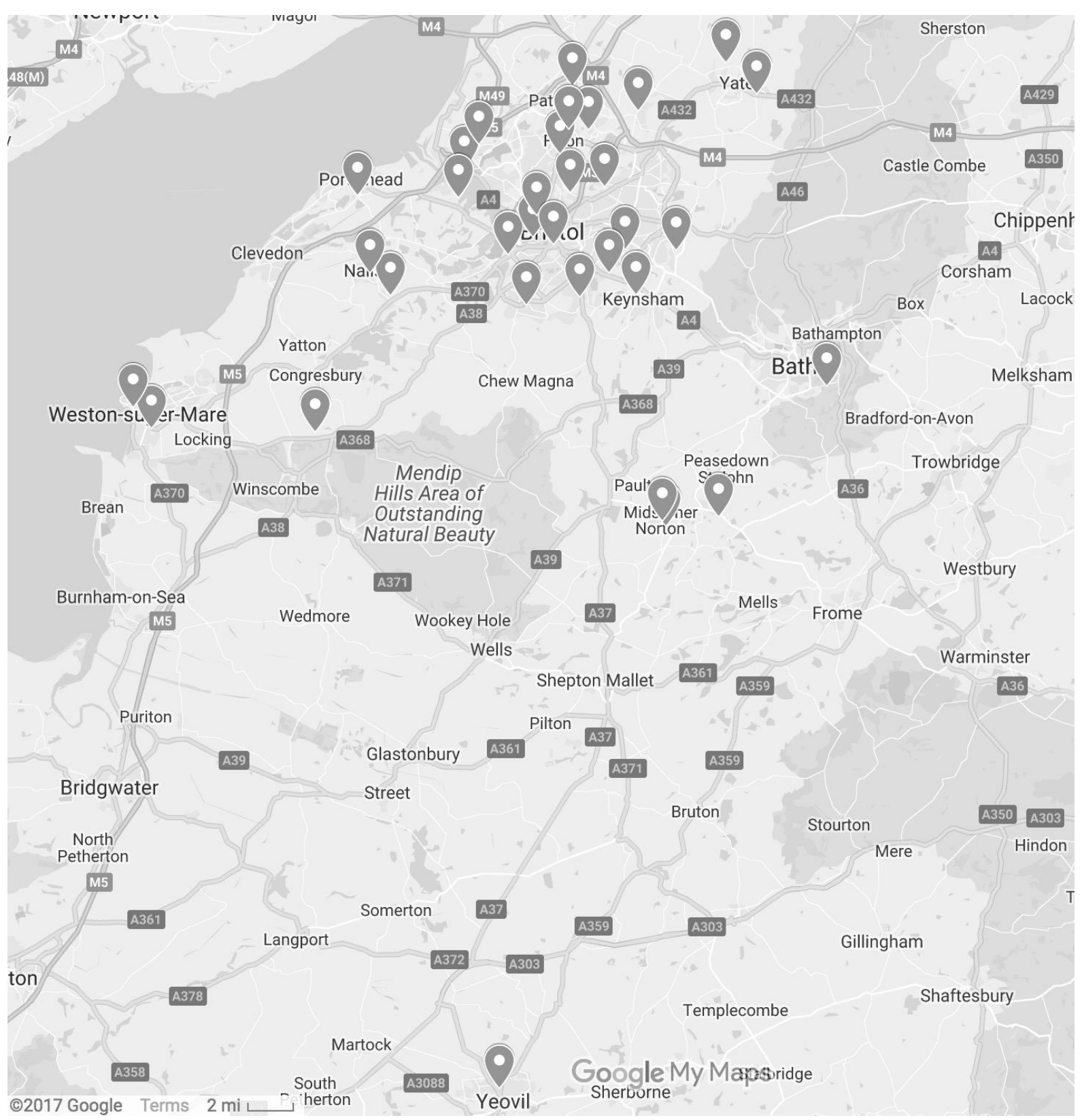


Figure 3: Acceptances of Offers from Russell Group universities, full sample

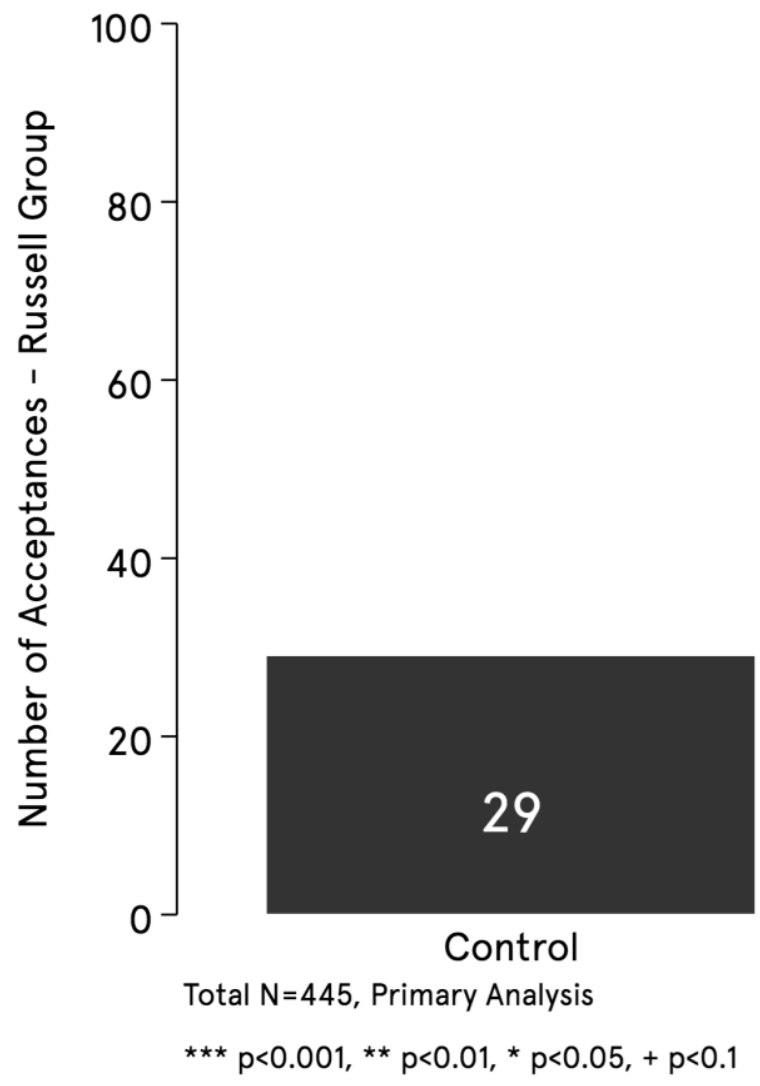

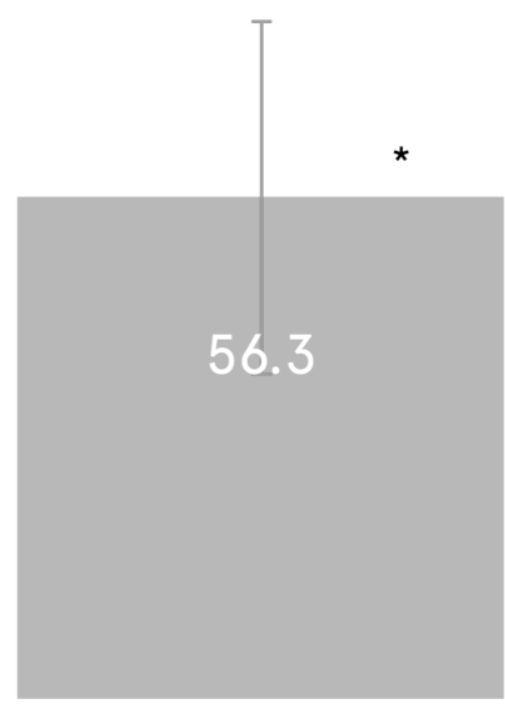

Talk 
Figure 4: Effect on Acceptances of Offers from Russell Group universities for College students
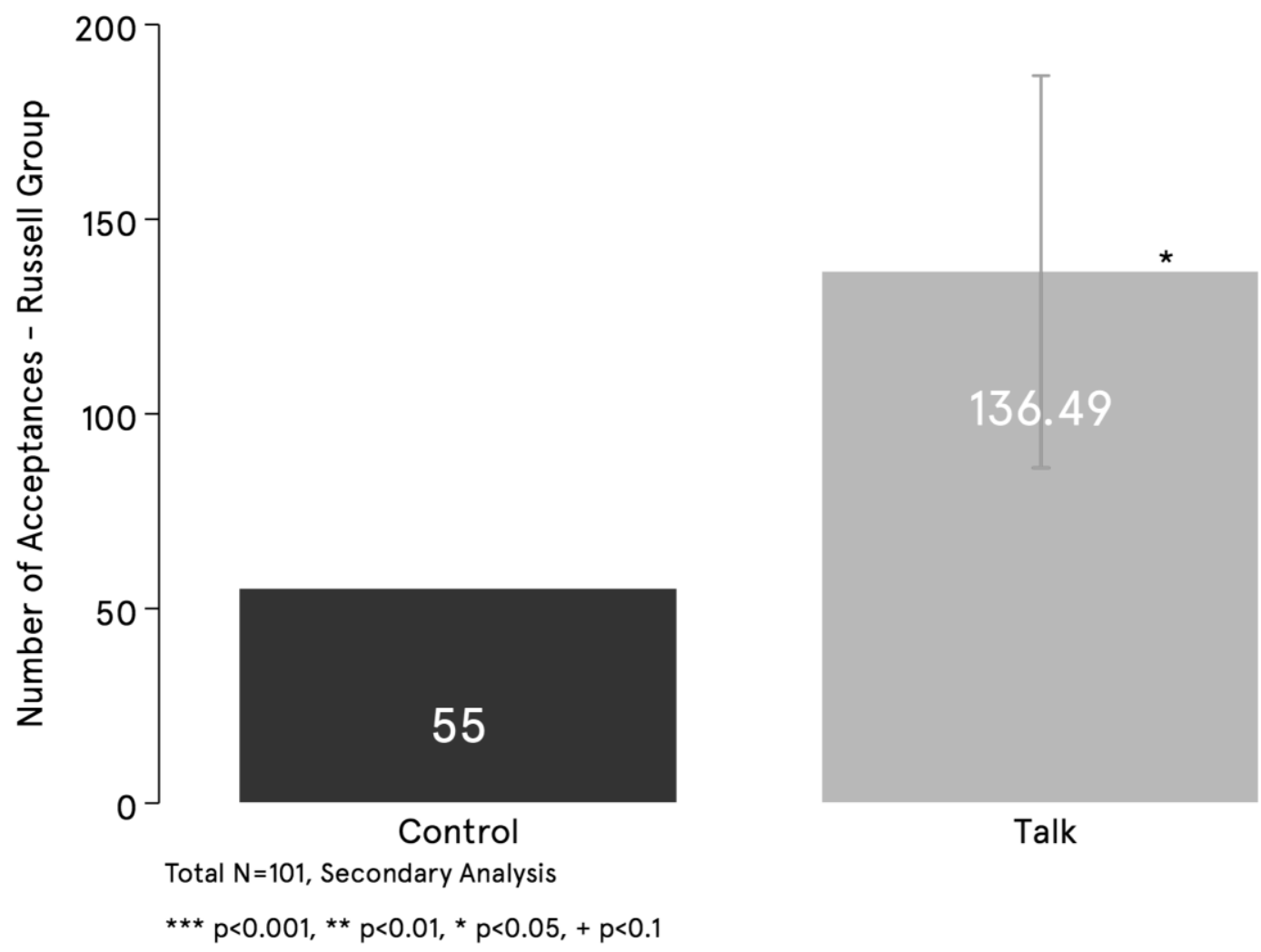
Figure 5: Effect on Acceptances of Offers from Russell Group universities for secondary school students

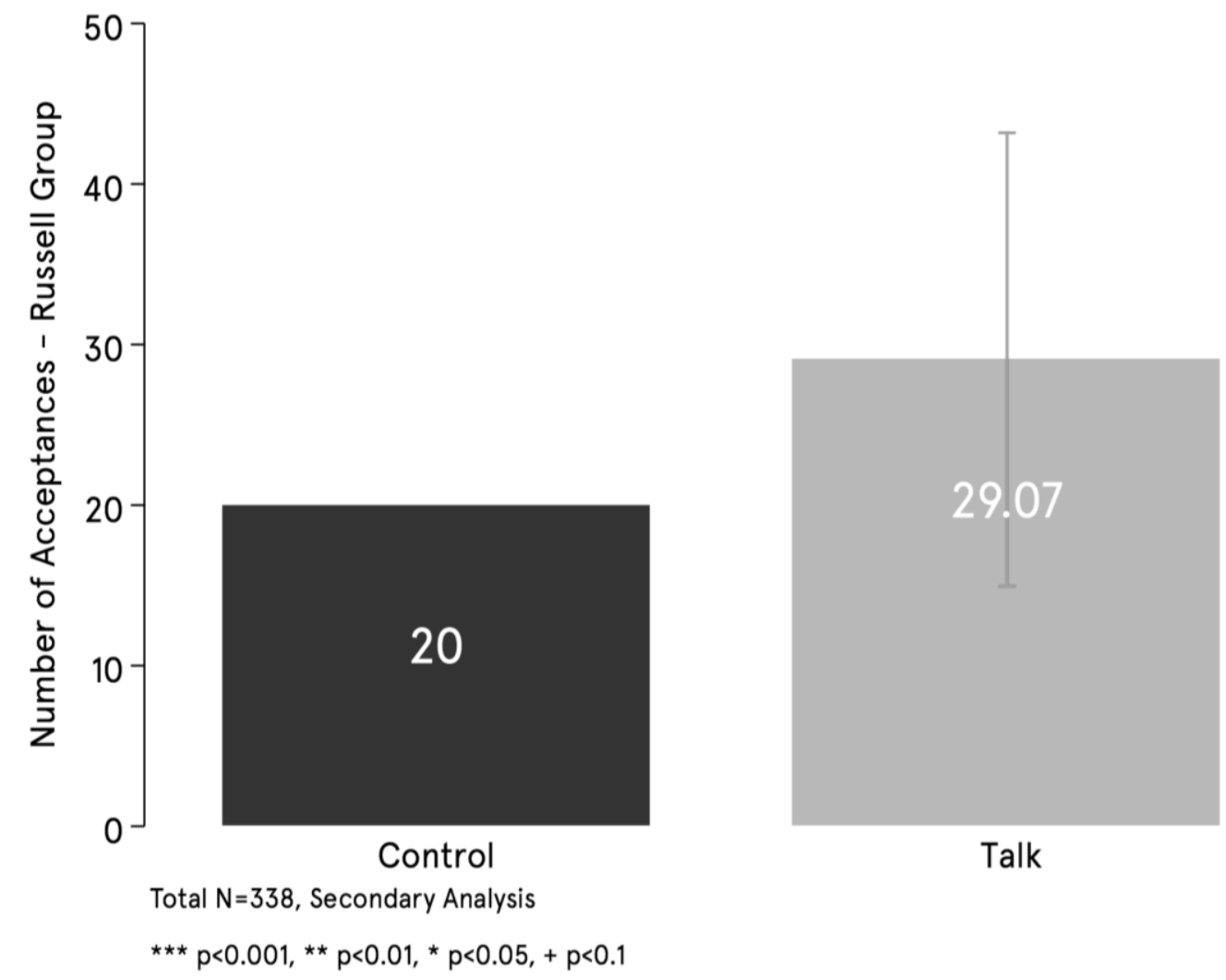

